\title{
Fate of copper in intensive shrimp farms: bioaccumulation and deposition in pond sediments
}

\author{
Lacerda, LD. *, Santos, JA. and Lopes, DV. \\ Laboratório de Biogeoquímica Costeira, Instituto de Ciências do Mar, \\ Universidade Federal do Ceará - UFC, \\ Av. Abolição, 3207, CEP 60165-081, Fortaleza, CE, Brazil \\ *e-mail: ldrude@pq.cnpq.br \\ Received May 7, 2008 - Accepted June 18, 2008 - Distributed August 31, 2009
}

(With 4 figures)

\begin{abstract}
We present the distribution of $\mathrm{Cu}$ in water, sediments and biomass from intensive shrimp (Litopenaeus vannamei Boone, 1931)) farming in northeastern Brazil. The results show no difference in dissolved $\mathrm{Cu}$ concentrations between waters entering and leaving the ponds. However, there was a large export of particulate $\mathrm{Cu}$ to adjacent environments, showed by extremely high particulate $\left(112 \mu \mathrm{g} . \mathrm{L}^{-1}\right) \mathrm{Cu}$ concentrations in draining waters. Copper concentrations in the bottom sediments of the pond varied with depth from 10 to $20 \mu \mathrm{g} \cdot \mathrm{g}^{-1}$, being 5 to 7 times higher than the local background. Pond management procedures result in a peculiar vertical distribution of $\mathrm{Cu}$ with peak values occurring at sub-surface depths in pond bottom sediments. Bioavailable $\mathrm{Cu}$ reaches about $20 \%$ of the total $\mathrm{Cu}$ content in sediments. Notwithstanding the relatively high $\mathrm{Cu}$ bioavailability, concentrations in shrimp muscle (23.2 to $63.4 \mu \mathrm{g} . \mathrm{g}^{-1}$ d.w.) were similar to reported values for reared and natural $L$. vannamei populations, and much lower than acceptable maximum limits for human consumption. Concentrations in the exoskeleton were always higher than in muscle. Increasing $\mathrm{Cu}$ mass, and to a lesser extent $\mathrm{Cu}$ concentrations in muscle tissues, occurred simultaneously to a decrease in $\mathrm{Cu}$ mass and concentrations in the exoskeleton and vice versa, suggesting a dynamical exchange of $\mathrm{Cu}$ between the two compartments. Although $\mathrm{Cu}$ fate in intensive shrimp culture does not result in increasing $\mathrm{Cu}$ exposure to consumers, the activity is an important source of this metal to adjacent ecosystems, in particular in the pristine environments where most aquaculture activities in NE Brazil takes place.
\end{abstract}

Keywords: intensive shrimp farming, copper, copper export and accumulation, northeastern Brazil.

\section{Dinâmica do cobre na carcinicultura intensiva: bioacumulação e deposição em sedimentos de tanques de criação}

\begin{abstract}
Resumo
Este trabalho apresenta a distribuição de $\mathrm{Cu}$ em água, sedimentos e biomassa em uma fazenda de cultivo intensivo do camarão Litopenaeus vannamei Boone, 1931, no Nordeste do Brasil. Os resultados mostraram não haver diferenças entre as concentrações de $\mathrm{Cu}$ nas águas afluentes e efluentes da fazenda. Entretanto, foi verificada uma grande exportação de $\mathrm{Cu}$ para áreas adjacentes associada ao material em suspensão. Nas águas efluentes, a concentração de $\mathrm{Cu}$ particulado atingiu até $112 \mu \mathrm{g} . \mathrm{L}^{-1}$. Em sedimentos, as concentrações de $\mathrm{Cu}$ variaram com a profundidade da coluna sedimentar de 10 a $20 \mu \mathrm{g} \cdot \mathrm{g}^{-1}$, sendo estes valores de 5 a 7 vezes mais altos que as concentrações naturais dos solos e sedimentos locais. O manejo dos tanques de criação resulta em perfis de distribuição de $\mathrm{Cu}$ em sedimentos com maiores concentrações em subsuperfície. A biodisponibilidade do $\mathrm{Cu}$ nestes sedimentos é elevada e atinge cerca de $20 \%$ da concentração total. Apesar da biodisponibilidade elevada, as concentrações de $\mathrm{Cu}$ em músculo do L. vannamei (23.2 a $63.4 \mu \mathrm{g} . \mathrm{g}^{-1}$ peso seco) são similares aos valores reportados para populações naturais da espécie e em diversos de cultivo em outros países, e estão bem abaixo dos limites máximos permitidos para consumo humano. As concentrações de $\mathrm{Cu}$ no exoesqueleto foram maiores que no músculo. Um aumento da massa de $\mathrm{Cu}$ em músculo ocorreu simultaneamente à diminuição do $\mathrm{Cu}$ no exoesqueleto e vice-versa sugerindo uma troca dinâmica do $\mathrm{Cu}$ entre os dois compartimentos. Embora a presença do Cu no cultivo intensivo do L. vannamei não represente exposição significativa para os consumidores, a atividade é fonte importante de $\mathrm{Cu}$ para os sistemas aquáticos adjacentes.
\end{abstract}

Palavras-chave: carcinicultura intensiva, cobre, exportação e acumulação de $\mathrm{Cu}$, Nordeste do Brasil. 


\section{Introduction}

Intensive shrimp aquaculture is a recent development of the Brazilian agribusiness but has increased by about $20 \%$ per year during the last decade, particularly along the semi-arid NE coast of Brazil due to the optimal climate and environmental setting. Production revenue increased from a few thousand dollars in the 1980 's to over 240 million in 2004, while shrimp farming area increased from less than 100 ha in 1998 to over 14,000 ha in 2004. Of these, 11,050 ha are located along the NE coast with an average annual production of about 66,000 tons (ABCC, 2005).

On the Jaguaribe River estuary, in Ceará State, shrimp pond area increased from 820 ha in 2001 to 1,260 ha in 2003 and 1,520 ha in 2004. Annual total production in 2001 reached 5,200 tons increasing to 11,370 tons in 2003 . Average productivity also increased from 6.3 t.ha $^{-1 / y e a r}$ to 8.2 t.ha $^{-1} /$ year between 2001 and 2003. In 2004, there was an increase in the number of farms (98) and pond area (1,520 ha), but a decrease in the annual production (7,560 tons) and productivity (5.2 $\mathrm{tha}^{-1 / y e a r) ~ d u e ~ t o ~ t h e ~ s p r e a d ~ o f ~ t y p i c a l ~ s h r i m p ~ i l l-~}$ ness and worsening environmental conditions, resulting in high (>50\%) death rates (MAPA, 2001; ABCC, 2005; Rocha and Rodrigues, 2004).

A survey of metal inputs from anthropogenic sources into the Jaguaribe estuary suggested that about $9.3 \mathrm{t}$ of $\mathrm{Cu}$ is emitted to the estuary, mostly from agriculture and urban sources (Lacerda and Sena, 2005) and can eventually affect adjacent shrimp farms. Also, $\mathrm{Cu}$ is a ubiquitous metal present in aquafeeds, as impurities in fertilizers and as active principles of pesticides used in the activity (Boyd and Massaut, 1999; Tacon and Forster, 2003). Copper is toxic to phytoplankton and the shrimps proper (Bainy, 2000; Chen and Lin, 2001; Lee and Shiau, 2002).

On the Jaguaribe estuary, Lacerda et al. (2006) stated that $\mathrm{Cu}$ emission factor from local shrimp aquaculture reached $386.4 \mathrm{~g} . \mathrm{ha}^{-1} / \mathrm{year}$, with total input into the estuary reaching $0.49 \mathrm{t} / \mathrm{year}$. The study also estimated that about $31.5 \mathrm{~g} \cdot \mathrm{ha}^{-1} / \mathrm{year}$ of $\mathrm{Cu}$ are accumulated in pond sediments and this may pose a long-term toxicological threat to reared animals.

In the present study, we investigated the fate of $\mathrm{Cu}$ in intensive shrimp farms at the Jaguaribe estuary, in particular $\mathrm{Cu}$ accumulation in shrimps during a typical growth cycle and accumulation and availability of $\mathrm{Cu}$ in pond sediments.

\section{Material and Methods}

The lower Jaguaribe estuarine basin (Figure 1), Ceará State in northeastern Brazil, covers about $1,735 \mathrm{~km}^{2}$ and has nearly 90,000 inhabitants. The regional climate is semi-arid, with average annual rainfall varying from 400 to $1,100 \mathrm{~mm}$. Coastal sandy plains with large aeolean dune fields, driven by the nearly year-round constant winds from the SE, dominates the coastline (Figure 1).



Figure 1. Location of the studied farms at the Jaguaribe River estuary, NE Brazil and of sampling stations for water and sediment samples. 1) Fluvial intake, 2) Water distribution canal, 3) Pond at the beginning of the growth cycle, 4) Pond at the end of the growing cycle, 5) Draining water canal, and 6) Output canal at a mangrove creek.

Maximum tidal amplitude reaches $2.8 \mathrm{~m}$ and the frequent small freshwater supply results in salinity intrusion up to $32 \mathrm{~km}$ inland. The tidal flood plain is covered by about 11,640 ha of mangroves. Freshwater discharge has been affected by the building of dams, water withdrawn for urbanization, agriculture and aquaculture. Rainy season maximum freshwater flow decreased from $200 \mathrm{~m}^{3} / \mathrm{s}$ before 1960 to about $20 \mathrm{~m}^{3} / \mathrm{s}$ (Marins et al., 2002). Therefore, dilution capacity of the estuary has been decreasing over the past decades, maximizing the potential effect of pollutant emissions from anthropogenic sources. 
Samples for $\mathrm{Cu}$ determination were collected following the same design shown in Figure 1, during one growth cycle in two different farms using similar production technologies, one under saline conditions $(\mathrm{S}=21.5 \pm 11.9)$ and the other with a brackish water regime $(S=14.3 \pm 11.6)$, using clean procedures. Water samples were collected in the inflow canal, inside two ponds (at the beginning and end of a production cycle) and in the outflow canal using pre-cleaned 1.5 L PET bottles. Samples were filtered for no longer than 3 hours from collecting through an acid-cleaned cellulose acetate filter with $0.45 \mu$ of pore diameter for the collection of total suspended solids.

Superficial bottom sediments were sampled by hand directly in pre-cleaned plastic bags in different sites of the ponds and the canals. Sediment cores were collected by inserting PVC tubes $(9.0 \mathrm{~cm}$ in diameter $)$ to $1.0 \mathrm{~m}$ of depth in the sedimentary column of 7 ponds among the two farms (two samples per pond).

Shrimps were collected at roughly 2 week intervals during a complete growth cycle in the two farms. Composite sub-samples of muscle tissue and exoskeleton from 5 to 10 individuals were used for analysis.

The filter with particulate matter and shrimps were kept frozen until analysis. These samples were ovendried to constant weight and, with the exception of sediment samples aliquots used for sequential geochemical extractions, were ashed $\left(450{ }^{\circ} \mathrm{C} / 24\right.$ hours $)$ to remove the organic matter prior to analysis.

Filtered water samples were acidified and UV-treated to release $\mathrm{Cu}$ from any eventually present strong organic complexes. $\mathrm{Cu}$ concentrations were determined by graphite furnace atomic absorption spectrophotometry.

Ashes from solid samples (particulate matter and shrimps) were digested in $20 \mathrm{~mL}$ of $50 \%$ aqua regia solution for 2 hours in Teflon crucibles at $80{ }^{\circ} \mathrm{C}$. Simultaneously, standard reference material NIST 2976 (mollusk tissue) and NIST 1646a (estuarine sediments) were treated similarly.

Sequential extractions for $\mathrm{Cu}$ followed Fiszman et al. (1984) including a weakly-bound $\mathrm{Cu}$, extracted with $0.1 \mathrm{~N} \mathrm{HCl}$; followed by strongly-bound $\mathrm{Cu}$, extracted with aqua regia. Weakly-bound $\mathrm{Cu}$ roughly corresponds to the sum of exchangeable $\mathrm{Cu}$, carbonate-bound $\mathrm{Cu}$ and $\mathrm{Cu}$ adsorbed to organic matter and non-crystalline Fe and Mn hydro-oxides (Fiszman et al., 1984). Sulfide precipitated $\mathrm{Cu}$ is not a significant fraction in aquaculture sediments due to the deepened oxidizing layer on the pond bottom caused by pond management (Liu and Zhao, 2007). Therefore, weakly-bound $\mathrm{Cu}$ roughly corresponds to the bioavailable fraction.

All digestion extracts were analyzed by conventional flame atomic absorption spectrophotometry in a Shimadzu AA-6200 spectrophotometer. Table 1 shows the comparison between certified and measured concentrations showing good recuperation of the certified concentrations, $92 \%$ for mollusk tissue and $88 \%$ for estuarine sediments.

\section{Results and Discussion}

\subsection{Copper concentrations in water and suspended solids}

Variation in $\mathrm{Cu}$ concentrations in the suspended solids and particulate and dissolved $\mathrm{Cu}$ concentrations in water at the different sampling sites within the saline farm are presented in Figure 2. Dissolved $\mathrm{Cu}$ concentrations were practically constant along the studied gradient, ranging from $6.7 \pm 0.2 \mu \mathrm{g} . \mathrm{L}^{-1}$ at the farm water intake point to a maximum of $7.4 \pm 0.3 \mu \mathrm{g} . \mathrm{L}^{-1}$ in draining waters. This apparent increase in dissolved $\mathrm{Cu}$ concentrations is, however, not statistically different from the other measured values.

Particulate $\mathrm{Cu}$ varied from 3.6 to $9.6 \mu \mathrm{g} . \mathrm{L}^{-1}$ during the growing cycle but presented a large concentration peak in waters draining the ponds (station 5), reaching $112 \mu \mathrm{g} . \mathrm{L}^{-1}$. Although the $\mathrm{Cu}$ content in the suspended solids also increased from 38.4 to $58.3 \mu \mathrm{g} . \mathrm{g}^{-1}$ in the intake canal and pond waters to $66.8 \mu \mathrm{g} . \mathrm{g}^{-1}$ in draining waters, changes in concentrations are not the major factor responsible for the large particulate $\mathrm{Cu}$ measured in draining waters, rather these high particulate $\mathrm{Cu}$ concentrations result mostly from an enormous increase in total load of suspended solids to the canal waters, which increased form a range of $87-164 \mathrm{mg} . \mathrm{L}^{-1}$, in the intake canal and pond waters to $1,675 \mathrm{mg} . \mathrm{L}^{-1}$ in draining waters. Most of this large particulate export occurs at the end of the draining process, when the water-sediment interface, mostly constituted with a nefloid layer, is carried into the draining flux (Figueiredo et al., 2005; Lacerda et al., 2006). Therefore, most $\mathrm{Cu}$ emission from these farms occurs through particulate $\mathrm{Cu}$ exportation.

\section{2. $\mathrm{Cu}$ accumulation in pond sediments}

Average $\mathrm{Cu}$ concentrations varied between 2.2 and $9.3 \mu \mathrm{g} . \mathrm{g}^{-1}$ in superficial sediments $(0-10 \mathrm{~cm})$ of the water intake canal increasing to concentrations varying from 10.6 to $15.2 \mu \mathrm{g} . \mathrm{g}^{-1}$ in sediments of the draining canal. Pond superficial bottom sediments $(0-10 \mathrm{~cm})$ average $\mathrm{Cu}$ concentrations were also higher than those of the intake canal but similar to those of the draining canal varying from 9.3 and $19.4 \mu \mathrm{g} . \mathrm{g}^{-1}$. There was no significant difference between $\mathrm{Cu}$ concentrations in sediments measured in the saline and brackish water farms.

Average $\mathrm{Cu}$ concentrations in the studied shrimp pond sediments are in the same range of those reported for other shrimp pond sediments by Gosavi et al. (2004) in Australia and by Sonnenholzer and Boyd (2000) in Ecuador. Although natural soil properties do affect $\mathrm{Cu}$ concentrations in pond sediments, farming management practices, aquafeeds and fertilizers added to ponds probably play a more important role in determining metal concentrations in shrimp pond sediments (Sonnenholzer and Boyd, 2000). For example, our results showed $\mathrm{Cu}$ concentrations 10-times lower that those reported for catfish ponds. Catfish farming adds about $12.5 \mathrm{~kg} \cdot \mathrm{ha}^{-1}$ of $\mathrm{Cu}$ yearly mostly as $\mathrm{Cu}$ sulfate, the most common- 
Table 1. Comparison between $\mathrm{Cu}$ concentrations ( $\mu$ g. $\mathrm{g}^{-1}$ d.w.), mean and standard deviation, in certified reference sediment samples (National Institute of Standards \& Technology - NIST) with those analyzed in the present study.

\begin{tabular}{lcccc}
\hline \multicolumn{1}{c}{ Standard } & n & Certified value & Measured value & Recuperation $(\%)$ \\
\hline NIST 1646a Estuarine Sediment & 6 & $10.01 \pm 0.34$ & $8.8 \pm 0.1$ & $87.9 \pm 1.0$ \\
NIST 2976 Mollusk tissue & 6 & $4.02 \pm 0.33$ & $3.7 \pm 0.3$ & $92.0 \pm 7.4$ \\
\hline
\end{tabular}

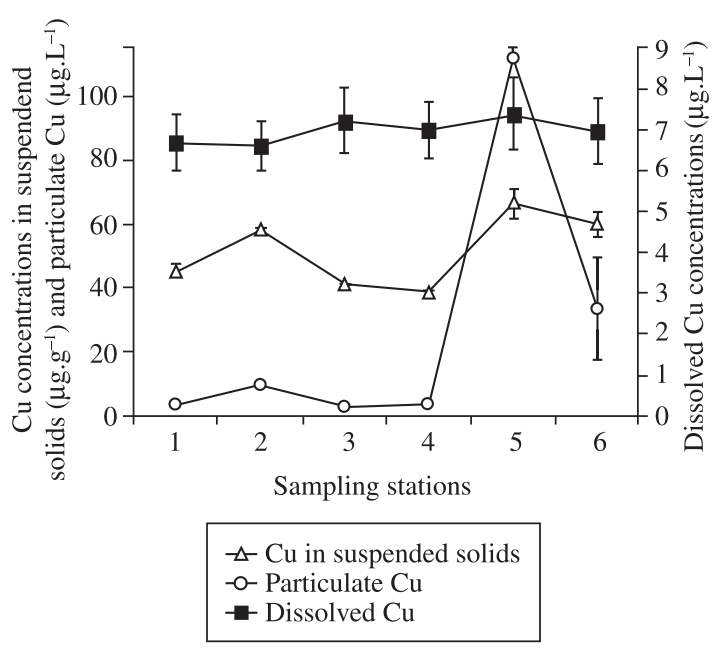

Figure 2. Variation in $\mathrm{Cu}$ concentrations in the suspended solids and particulate and dissolved copper concentrations in water in different sites within the studied saline farm. 1) River upstream the intake, 2) Intake canal, 3) Pond at the beginning of the growth cycle, 4) Pond at the end of the growing cycle, 5) Draining water, and 6) End of the output canal. No data is available for the brackish water farm.

ly used algaecide for freshwater aquaculture (Liu and Zhao, 2007), whereas shrimp farming adds only about 400 g.ha ${ }^{-1}$ of $\mathrm{Cu}$ yearly, mostly as a natural constituent of aquafeeds and fertilizers (Lacerda et al., 2006).

Geochemical partitioning of $\mathrm{Cu}$ along the sediment profile showed weakly-bound $\mathrm{Cu}$ representing $19 \%$ of the total $\mathrm{Cu}$ concentration at the surface to $20 \mathrm{~cm}$, increasing to $23 \%$ to $27 \%$ from 30 to $70 \mathrm{~cm}$ and decreasing to $18 \%$ below this depth (Figure 3 ). The proportion of this bioavailable $\mathrm{Cu}$ is similar to the values reported by Liu and Zhao (2007) for catfish pond sediments, although at the surface, catfish sediment bioavailable $\mathrm{Cu}$ content is in general higher than the proportion reported here, probably as a result of the freshwater environment.

The accumulation of $\mathrm{Cu}$ in pond sediments is shown in Figure 3. Concentrations of the three geochemical $\mathrm{Cu}$ fractions $(0.1 \mathrm{HCl} \mathrm{N}$-extractable, Aqua Regia- extractable and total $\mathrm{Cu}$ ) showed similar vertical distribution, with concentrations increasing from the surface to about $30 \mathrm{~cm}$ depth, where all three fractions presented their maximum values. Maximum bioavailable $\mathrm{Cu}$ content also occurred at the depth (Figure 3). Below $30 \mathrm{~cm}$ all three fractions decreased to minimum values at $70 \mathrm{~cm}$ downward. At these depths, total $\mathrm{Cu}$ concentrations were 7-times lower than peak concentrations at $30 \mathrm{~cm}$ and 5-times lower than surface concentrations, but similar to $\mathrm{Cu}$ concentrations reported for local soils and sediments out of the influence of shrimp farms (Lacerda et al., 2005). This profile is different from most natural lotic sediments where concentration peaks generally occur at the surface of sediment profiles and is similar to metal distribution in sediments or soils submitted to erosion of the metal-richer surface layers (Elsenbeer, 2001) and is due to frequent surface sediment layer removal during pond draining as demonstrated by the $\mathrm{Cu}$ profiles found in 25-years old catfish ponds (Liu and Zhao, 2007). Our ponds aged about 11 years, therefore having been submitted to at least 25 draining cycles.

\subsection{Copper concentrations and mass in shrimp biomass}

The range of $\mathrm{Cu}$ concentrations measured in muscle tissues of L. vannamei reared in the Jaguaribe estuary was 23.2 to $63.4 \mu \mathrm{g} . \mathrm{g}^{-1}$, slightly higher than the range reported for natural and reared populations of this species, notwithstanding the relatively high $\mathrm{Cu}$ bioavailability in bottom sediments and the high concentrations measured in suspended matter. For example, Paez-Osuna and Ruiz-Fernádez (1995) and Paez-Osuna and Tron-Mayen (1996) reported concentrations varying from 22.7 to $27.5 \mu \mathrm{g} . \mathrm{g}^{-1}$ and 18.5 to $19.2 \mu \mathrm{g} . \mathrm{g}^{-1}$, in natural populations and farmed individuals of $L$. vannamei along the Mexican coast. In NE Brazil, Lopes and Lacerda (2005) reported $\mathrm{Cu}$ concentrations in muscle tissue of reared L. vannamei varying from 24.1 to $38.5 \mu \mathrm{g} . \mathrm{g}^{-1}$.

For the exoskeleton $\mathrm{Cu}$ concentrations were always higher than in muscle in both farms and varied from 49.9 to $112.2 \mu \mathrm{g} \cdot \mathrm{g}^{-1}$. However, the scarcity of data available in the literature hampers a better comparison. Although at least one study by Paez-Osuna and Tron-Mayen (1996) also reported $\mathrm{Cu}$ concentrations in the same range found in this study and also higher than respective muscle concentrations.

The results presented in Figure 4 show $\mathrm{Cu}$ concentration variation measured in L vannamei during one growth cycle and the respective total $\mathrm{Cu}$ mass in the animals, in the saline and brackish water farms. Concentrations and masses of $\mathrm{Cu}$ were similar in shrimps from both farms, probably reflecting the efficient osmotic control typical 




Figure 3. Vertical distribution of the three different $\mathrm{Cu}$ geochemical fractions in bottom sediments from shrimp farms at the Jaguaribe estuary, CE, NE Brazil. Average from 7 cores collected in duplicate in the saline and brackish water farms.

of this species as reported previously (Paez-Osuna and Ruiz-Fernádez, 1995).

In the saline farm, $\mathrm{Cu}$ concentrations (Figure $4 \mathrm{a}$ ) in the exoskeleton increased from $82.5 \mu \mathrm{g} \cdot \mathrm{g}^{-1}$ in the beginning of the cycle, reaching maximum values ranging from 103.7 to $112.2 \mu \mathrm{g} . \mathrm{g}^{-1}$ at the end of the first half of the cycle and then decreased to lower values $\left(62.1 \mu \mathrm{g} . \mathrm{g}^{-1}\right)$ at the end of the growth cycle. In the brackish water farm, however, $\mathrm{Cu}$ concentrations (Figure $4 \mathrm{~b}$ ) in the exoskeleton decreased throughout the cycle from 83.2-93.8 $\mu \mathrm{g} . \mathrm{g}^{-1}$ at the beginning of the cycle, to $49.9 \mu \mathrm{g} \cdot \mathrm{g}^{-1}$ on day 160 , but increased to $69.9 \mu \mathrm{g} . \mathrm{g}^{-1}$ during the last 10 days of the growth cycle.

Muscle concentrations in shrimp from the saline farm (Figure 4a) decreased during the beginning of the cycle from 61.3 to $24.6 \mu \mathrm{g} . \mathrm{g}^{-1}$ and increased to values similar to the beginning of the experiment at the end of the cycle. In the brackish water farm (Figure $4 \mathrm{~b}$ ), however, $\mathrm{Cu}$ concentrations in muscle also increased from $13.8 \mu \mathrm{g} . \mathrm{g}^{-1}$ in the beginning of the cycle to $63.6 \mu \mathrm{g} \cdot \mathrm{g}^{-1} \mathrm{on}$ day 160 , from then onward, concentrations decreased to $23.2 \mu \mathrm{g} . \mathrm{g}^{-1}$ on day 170 , at the end of the cycle.

There was an inverse correlation between $\mathrm{Cu}$ concentrations in muscle and exoskeleton $(r=-0.564, p>0.05$; $r=-0.216, p>0.1)$ in the saline farm and brackish water farm respectively), suggesting an exchange of $\mathrm{Cu}$ from muscle to the exoskeleton, probably in response to changing $\mathrm{Cu}$ concentrations, with the exoskeleton acting as both a source and a sink for $\mathrm{Cu}$, depending on metabolism necessities (Khan et al., 1989; Reinfelder and Fisher, 1994; Smokrowski et al., 1998).

The $\mathrm{Cu}$ mass in the exoskeleton increased throughout the first 80 days of the growing cycle in both farms, roughly following the same variation of the animal biomass. After, exoskeleton $\mathrm{Cu}$ mass decreased to the end of the cycle when again they increased, reaching maximum values at the very end of the cycle. In muscle, $\mathrm{Cu}$ mass was relatively constant during the first 80 days of the growth cycle reaching about $20 \mu \mathrm{g}$ of $\mathrm{Cu}$. This was followed by a sharp increase to $64.5 \mu \mathrm{g}$ at the end of the growth cycle in the saline farm (Figure $4 \mathrm{c}$ ) and to $63.6 \mu \mathrm{g}$ in day 160 in the brackish water farm, however, in this farm a subsequent decrease to $38.5 \mu \mathrm{g}$ occurred between days 160 and 170 (Figure 4d). The sharp increase in the total $\mathrm{Cu}$ mass in muscle tissues occurred simultaneously to a decrease in $\mathrm{Cu}$ mass of the exoskeleton, again suggesting a dynamical exchange of $\mathrm{Cu}$ between the two compartments.

There was no clear effect of $\mathrm{Cu}$ concentration or mass on shrimp biomass accumulation in the saline farm. Maximum dissolved $\mathrm{Cu}$ concentration $\left(7.4 \mu \mathrm{g} . \mathrm{L}^{-1}\right)$ found in pond water are much lower than the reported $\mathrm{Cu}$ LC50s for reared shrimps (4.500 $\left.\mu \mathrm{g} . \mathrm{L}^{-1}\right)($ Chen and Lin, 2001). However, in the brackish water farm, the animals 

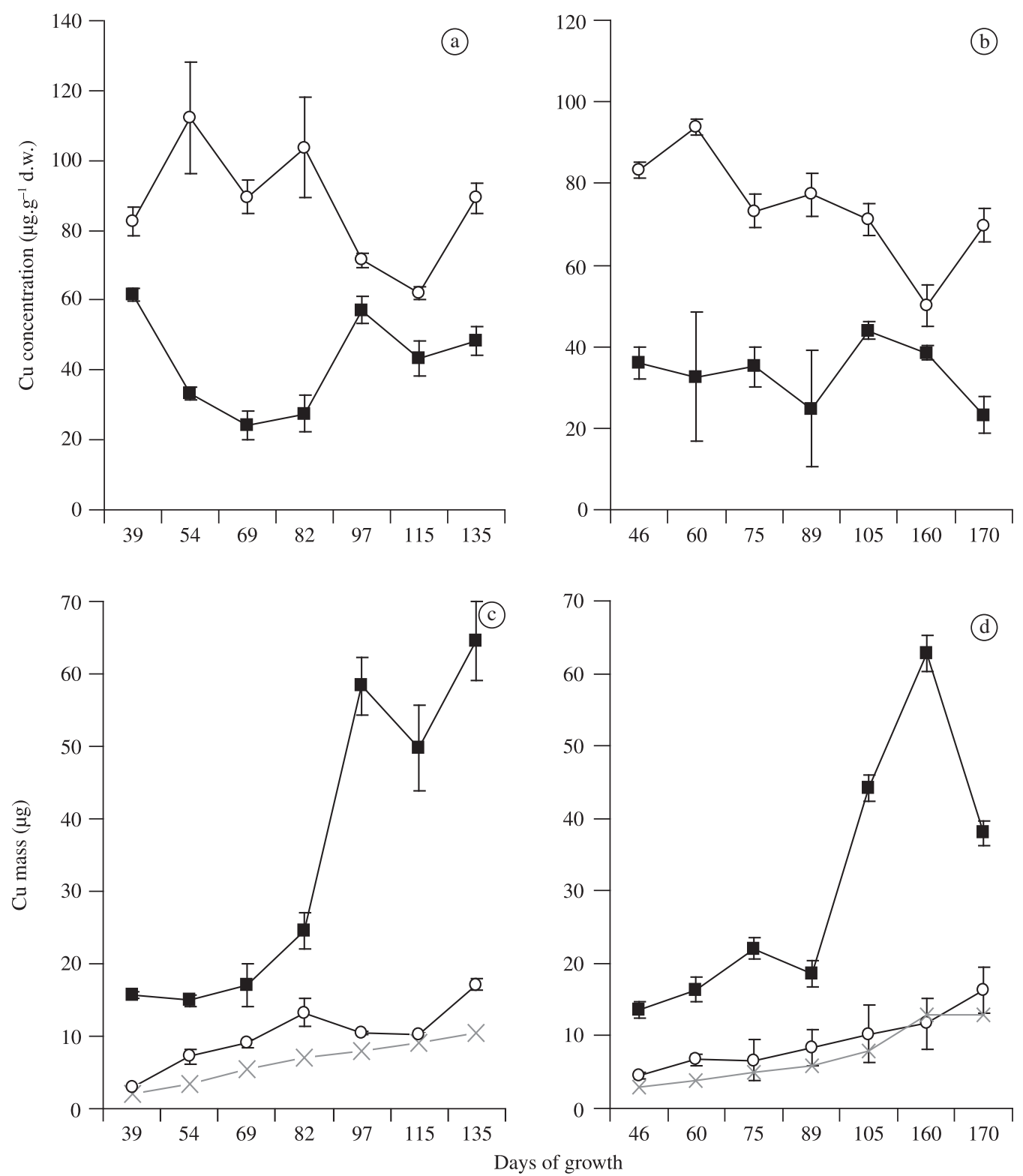

Days of growth

$\rightarrow$ Muscle $\longrightarrow$ - Exoskeleton $\longrightarrow$ Biomass $(\mathrm{g})$

Figure 4. Variation of $\mathrm{Cu}$ concentration and mass in Litopenaeus vannamei during one growth cycle in the saline (4a, 4c) and brackish water (4b, 4d) at farms on the Jaguaribe estuary, CE, NE Brazil.

showed no biomass increase in the last 10 days of the growing cycle, when a possible transfer of $\mathrm{Cu}$ from muscle to exoskeleton occurred as suggested by the $\mathrm{Cu}$ mass behavior showed in Figure 4d.

In relation to consumer exposure to $\mathrm{Cu}$ from the reared shrimps, the maximum concentration measured when converted to wet weight basis (about $15 \mu \mathrm{g} \cdot \mathrm{g}^{-1}$ ), is only half of the acceptable maximum concentration for $\mathrm{Cu}$ in seafood (ANVISA, 1998).

\section{Conclusions}

Export of $\mathrm{Cu}$ from shrimp farms to adjacent environments is significant and occurs mostly as particulate $\mathrm{Cu}$ due to the flowing out of the surface sediment layers during pond draining. This results in a peculiar vertical distribution of $\mathrm{Cu}$ reaching peak values at sub-surface depths in pond bottom sediments. Nevertheless, there is a considerable accumulation of $\mathrm{Cu}$ in pond bottom sedi- 
ments relative to local soil and sediment concentrations. Bioavailable $\mathrm{Cu}$ reaches about $20 \%$ of the total $\mathrm{Cu}$ content in sediments.

Notwithstanding the relatively high bioavailability, $\mathrm{Cu}$ concentrations in shrimps did not differ from reported values for other reared and natural shrimp populations. $\mathrm{Cu}$ concentrations and masses in shrimp biomass were independent of salinity. $\mathrm{Cu}$ concentrations in the exoskeleton were always higher than in muscle both under saline and brackish water conditions. Increasing $\mathrm{Cu}$ mass, and to a lesser extent $\mathrm{Cu}$ concentration, in muscle tissues occurred simultaneously to a decrease in $\mathrm{Cu}$ mass and concentration in the exoskeleton, suggesting a dynamical exchange of $\mathrm{Cu}$ between the two compartments.

Our results show that whereas $\mathrm{Cu}$ fate in intensive shrimp culture does not result in increasing $\mathrm{Cu}$ exposure to consumers, the activity is an important source of this metal to adjacent ecosystems, in particular in the pristine environments where most aquaculture activities in NE Brazil takes place.

Acknowledgements - This study was supported by the FINEPRECARCINE initiative and is part of the Instituto do Milênio program, Proc. No. 420.050/2005-1 from the National Research Council of Brazil (CNPq). The authors thank S. Mounier, Univ. Toulon, France, for helping with the chemical analysis of dissolved $\mathrm{Cu}$.

\section{References}

Agência Nacional de Vigilância Sanitária - ANVISA, 1998. Legislação em Vigilância Sanitária: Portaria No. 685, de 27 de agosto de 1998. Brasília: Ministério da Saúde.

Associação Brasileira dos Criadores de Camarão - ABCC, 2005. Censo da produção do camarão marinho cultivado. Recife: ABCC. Available from: <http://www.abcc.com.br>. Access in: Junho de 2007.

BAINY, ACD., 2000. Biochemical responses in penaeids caused by contaminants. Aquaculture, vol. 191, no. 1-3, p. 163-168.

BOYD, CE. and MASSAUT, L., 1999. Risks associated with the use of chemicals in pond aquaculture. Aquaculture Engineering, vol. 20, no. 2, p. 113-132.

CHEN, J. and LIN, C., 2001. Toxicity of copper sulfate for survival, growth, molting and feeding of juveniles of the tiger shrimp Penaeus monodon. Aquaculture, vol. 192, no. 1, p. $55-65$.

ELSENBEER, H., 2001. Hydrologic flow paths in tropical rainforest landscapes: a review. Hydrological Processes, vol. 15, no. 4, p. 1751-1759.

FIGUEIREDO, MCB., ARAÚJO, LFP., GOMES, RB., ROSA, MF., PAULINO, WD. and MORAIS, LFS., 2005. Impactos ambientais do lançamento de efluentes da carcinicultura em águas interiores. Engenharia Sanitária \& Ambiental, vol. 10, no. 2, p. 167-174.

FISZMAN, M., PFEIFFER, WC. and LACERDA, LD., 1984. Comparison of methods used for extraction and geochemical distribution of heavy metals in bottom sediments from Sepetiba
Bay, Rio de Janeiro. Environmental Technology Letters, vol. 5, no. 4, p. 567-575.

GOSAVI, K., SAMMUT, J., GIFFORD, S. and JANKOWSKI, J., 2004. Microbial biomonitores of trace metal contamination in acid sulfate soil aquaculture ponds. The Science of the Total Environment, vol. 324, no. 1, p. 25-39.

KHAN, AT., WEIS, JS. and D'ANDREA, L., 1989. Bioaccumulation of heavy metals in two populations of grass shrimp, Palaemonetes pugio. Bulletin of Environmental Contamination and Toxicology, vol. 42, no. 3, p. 339-343.

LACERDA, LD. and SENA, DD., 2005. Estimativas de cargas de nitrogênio, fósforo e metais pesados de interesse ambiental para as bacias inferiores do litoral do Estado do Ceará. Fortaleza: Secretaria de Meio Ambiente do Estado do Ceará; Programa de Zoneamento Ecológico e Econômico do Litoral do Ceará. Available from: www.semace.gov.ce/zee/produtos/. Access in: Junho de 2007.

LACERDA, LD., MARINS, RV., SILVA, FJ., AGUIAR, JE. and VAISMAN, AG., 2005. Heavy metals emissions and distribution along the Jaguaribe River lower basin, Northeastern Brazil. In Proceedings of the XIII International Conference in Heavy Metals in the Environment, May 15-18. Rio de Janeiro: CETEM. p. 718-721.

LACERDA, LD., SANTOS, JA. and MADRID, RM., 2006. Copper emission factors from intensive shrimp aquaculture. Marine Pollution Bulletin, vol. 52, no. 12, p. 1823-1826.

LEE, M. and SHIAU, S., 2002. Dietary copper requirement of juvenile grass shrimp Penaeus monodon and effects on non-specific immune response. Fish \& Shellfish Immunololgy, vol. 13 , no. 4, p. 259-270.

LIU, R. and ZHAO, D., 2007. The leachability, bioaccessibility, and speciation of cu in the sediment of channel catfish ponds. Environmental Pollution, vol. 147, no. 3, p. 593-603.

LOPES, DV. and LACERDA, LD., 2005. Determinação de metais-traço em camarões cultivados (Litopenaeus vannamei): possíveis impactos na produtividade. In Annals of the XIV Congresso Brasileiro de Engenharia de Pesca, October 18-22. Fortaleza: Universidade Federal do Ceará. p. 663-664.

MARINS, RV., FREIRE, GSS., MAIA, LP., LIMA, JPR. and LACERDA, LD., 2002. Impacts of land-based activities on the Ceará coast, NE Brazil. In LACERDA, LD., KREMER, HH., KJERFVE, B., SALOMONS, W., MARSHALL-CROSSLAND, JI. and CROSSLAND, JC. (Eds.). South American basins: LOICZ global change assessment and synthesis of river catchment: coastal sea interaction and human dimensions. Texel, The Netherlands: LOICZ Reports \& Studies. p. 92-98.

Ministério da Agricultura, Pecuária e Abastecimento - MAPA, 2001. Plataforma tecnológica do camarão marinho cultivado. Brasília: MAPA. 276p.

PAÉZ-OSUNA, F. and RUIZ-FERNÁNDEZ, C., 1995. Trace metals in Mexican shrimp Penaeus vannamei from estuarine and marine environments. Environmental Pollution, vol. 87, no. 2, p. 243-247.

PAÉZ-OSUNA, F. and TRON-MAYEN, L., 1996. Concentration and distribution of heavy metals in tisúes of wild and farmed shrimp Penaeus vannamei from the northwest coast of Mexico. Environment International, vol. 4, no. 5-6, p. 443-450.

REINFELDER, JR. and FISHER, NS., 1994. Retention of elements adsorbed by juvenile fish (Menidia menidia, Menidia 
beryllina) from zooplankton prey. Limnology \& Oceanography, vol. 39 , no. 8 , p. 1783-1789.

ROCHA, IP. and RODRIGUES, J., 2004 O agronegócio do camarão cultivado em 2003. Recife: Associação Brasileira de Criadores de Camarão. 43p.

SMOKROWSKI, KE., LASENDY, DC. and EVANS, RD., 1998. Quantifying the uptake and release of cadmium and copper by the opossum shrimp Mysis relictal preying upon the cladoceran
Daphnia magna using stable isotope tracers. Canadian Journal of Fisheries \& Aquatic Sciences, vol. 55, no. 4, p. 909-916.

SONNENHOLZNER, S. and BOYD, CE., 2000. Chemical and physical properties of shrimp pond bottom soils in Ecuador. Journal of the World Aquaculture Society, vol. 31, no. 3, p. 358-375.

TACON, AGJ. and FORSTER, IP., 2003. Aquafeeds and the environment: policy implications. Aquaculture, vol. 226, no. 1-4, p. 181-189. 